\title{
Physiologically based modeling of lisofylline pharmacokinetics following intravenous administration in mice
}

\author{
Elżbieta Wyska • Artur Świerczek • \\ Krzysztof Pociecha $\cdot$ Katarzyna Przejczowska-Pomierny
}

Received: 16 September 2014/ Accepted: 28 January 2015/Published online: 8 February 2015

(c) The Author(s) 2015. This article is published with open access at Springerlink.com

\begin{abstract}
Lisofylline (LSF), is the R-(-) enantiomer of the metabolite M1 of pentoxifylline, and is currently under development for the treatment of type 1 diabetes. The aim of the study was to develop a physiologically based pharmacokinetic (PBPK) model of LSF in mice and to perform simulations in order to predict LSF concentrations in human serum and tissues following intravenous and oral administration. The concentrations of LSF in serum, brain, liver, kidneys, lungs, muscle, and gut were determined at different time points over $60 \mathrm{~min}$ by a chiral HPLC method with UV detection following a single intravenous dose of LSF to male CD-1 mice. A PBPK model was developed to describe serum pharmacokinetics and tissue distribution of LSF using ADAPT II software. All pharmacokinetic profiles were fitted simultaneously to obtain model parameters. The developed model characterized well LSF disposition in mice. The estimated intrinsic hepatic clearance was $5.427 \mathrm{ml} / \mathrm{min}$ and hepatic clearance calculated using the well-stirred model was $1.22 \mathrm{ml} / \mathrm{min}$. The renal clearance of LSF was equal to zero. On scaling the model to humans, a good agreement was found between the predicted by the model and presented in literature serum LSF concentration-time profiles following an intravenous dose of $3 \mathrm{mg} /$ $\mathrm{kg}$. The predicted LSF concentrations in human tissues following oral administration were considerably lower despite the twofold higher dose used and may not be sufficient to exert a pharmacological effect. In conclusion, the mouse is a good model to study LSF pharmacokinetics
\end{abstract}

E. Wyska $(\bowtie) \cdot$ A. Świerczek · K. Pociecha .

K. Przejczowska-Pomierny

Department of Pharmacokinetics and Physical Pharmacy,

Jagiellonian University Medical College, 9 Medyczna St.,

30-688 Cracow, Poland

e-mail: mfwyska@cyf-kr.edu.pl following intravenous administration. The developed PBPK model may be useful to design future preclinical and clinical studies of this compound.

Keywords Lisofylline - PBPK model $\cdot$ Mice · Simulations $\cdot$ Human tissues

\section{Introduction}

Lisofylline (LSF), (-)-R-1-(5-hydroxyhexyl)-3,7-dimethylxanthine (Fig. 1), is an enantiomer of the metabolite M1 of pentoxifylline. It is currently under development for the treatment of type 1 diabetes (Yang et al. 2005; National Institutes of Health 2009). LSF reduces the impairment of insulin secretion induced by IL- $1 \beta$ in cultured rat islet cells (Bleich et al. 1996), suppresses IFN- $\gamma$ production, the onset of diabetes, and macrophage infiltration into islets from NOD mice (Yang et al. 2002), as well as it improves insulin response and lowers glucose levels in streptozotocintreated rats after the oral glucose tolerance test (Striffler and Nadler 2004). It has been shown that LSF prevents $\beta$ cell dysfunction in NOD mice by inhibition of STAT4 phosphorylation which interrupts IL-12 signaling (Yang et al. 2003). Moreover, this compound ameliorates experimental allergic encephalomyelitis in mice (Bright et al. 1998). As a STAT 4 inhibitor it may be also potentially useful in other autoimmune disorders (Liang et al. 2014). LSF has been shown to inhibit lysophosphatidic acid acyltransferase with an $\mathrm{IC}_{50}$ of $0.6 \mu \mathrm{M}$ in lipopolysaccharide (LPS) stimulated P388 cell line (Rice et al. 1994a). It is well known that phosphatidic acid (PA) is a crucial mediator involved in pro-inflammatory cytokine release, acting via Akt-mTOR-p70 S6K pathway. LSF also improves survival in mice injected with a lethal dose of LPS 
(Rice et al. 1994a) and ameliorates sepsis-induced lung injury in minipigs (Hasegawa et al. 1997). Moreover, in rats given IL-1 intratracheally LSF pretreatment reduced lung leak but did not decrease neutrophil accumulation in lungs (Hybertson et al. 1997). However, clinical trials of LSF for the treatment of acute lung injury or acute respiratory distress syndrome showed no evidence of improved survival rate of patients with serious infections, or organ failure-free days, and decreased free fatty acids in serum (ARDS Clinical Trials Network et al. 2002). LSF is also known to suppress release of TNF- $\alpha$ in vivo in mice (Rice et al. 1994a; Wyska 2009, 2010a) and ex vivo in human blood stimulated with endotoxin derived from Salmonella or Escherichia coli (Rice et al. 1994b). In addition, it abrogates the synthesis of TNF- $\alpha$ or IL- $1 \beta$ and stimulates the production of IL-10 in human leukocytes in vitro (van Furth et al. 1997). Mice treated with LSF after hemorrhage exhibited reduced lung edema, intraalveolar hemorrhage, pulmonary interstitial neutrophils and BAL leukocytes compared to untreated mice (Abraham et al. 1995). In patients receiving the allogenic bone marrow transplantation the treatment with $3 \mathrm{mg} / \mathrm{kg}$ LSF resulted in an improved 100-day survival compared to placebo or $2 \mathrm{mg} / \mathrm{kg}$ LSF treated patients (List et al. 2000). Treatment with LSF improves hematological recovery after 5-fluorouracil treatment possibly by inhibition of TGF- $\beta$ and abrogates the release of hematopoietic inhibitors induced by chemotherapy in mice (Clarke et al. 1996; Vries and Singer 2000). However, in humans LSF treatment failed to alter the toxicities of high-dose IL-2 in renal cancer or malignant melanoma patients (Margolin et al. 1997).

In order to exert its pharmacologic activity the drug should attain therapeutic concentrations at the site of action. One of the reasons for the lack of efficacy in clinical trials may be inappropriate concentration of the drug in the target tissues. Physiologically based pharmacokinetic (PBPK) modeling in animals allows for the prediction of drug concentration both in human plasma and tissues. Classical pharmacokinetic models consist of a small number of compartments (1-3 in most cases) that have a limited physiological meaning. They are useful to estimate pharmacokinetic parameters but have many limitations. PBPK models include a larger number of compartments<smiles>C[C@H](O)CCCCn1c(=O)c2c(ncn2C)n(C)c1=O</smiles>

Fig. 1 Chemical structure of LSF corresponding to anatomical spaces and intercompartmental blood flow as well as incorporate the biochemical and physiochemical parameters of the drug under investigation. They are very useful not only to describe pharmacokinetics of a drug, but also to extrapolate a dose between species or populations or routes of administration (Jones et al. 2006). Pharmacokinetic properties of LSF following intravenous and oral administration were previously studied in mice (Wyska et al. 2006, 2007, Wyska 2010b). Limited information exists on the pharmacokinetics of LSF in human subjects. Only in one human study the pharmacokinetics of this compound in plasma was assessed after a short intravenous infusion and oral administration using noncompartmental analysis (Bursten et al. 1998).

The aim of this study was to develop a PBPK model using plasma and tissue concentration-time data obtained following intravenous administration of LSF to mice. Moreover, based on this model and human organ weights, blood flows and biochemical data, simulations were performed to predict LSF concentrations in human serum and tissues following intravenous and oral administration of this compound.

\section{Materials and methods}

\subsection{Chemicals}

Lisofylline was obtained in the Department of Technology and Biotechnology of Drugs, Jagiellonian University Collegium Medicum. Temazepam was a gift from Polfa (Poland). All other chemicals were of HPLC or analytical reagent grade and were purchased from Merck (Darmstadt, Germany).

\subsection{Pharmacokinetic study}

Male Crl:CD-1 (8-10 weeks old) mice weighing $30.25 \pm 2.11 \mathrm{~g}$, bred in-house from progenitors obtained from Charles River Laboratories (Sulzfed, Germany) were used in this study. Animals were fasted overnight prior to drug administration but had free access to water. All animal procedures were approved by the Local Ethical Committee on Animal Testing at the Jagiellonian University in Cracow. LSF $(50 \mathrm{mg} / \mathrm{kg}$ ) was given into the tail vein, and animals (3-4 per time point) were exsanguinated at different time points after compound administration up to 60 min. Tissues, such as brain, muscle, kidneys, liver, gut, and lungs were harvested. Blood was allowed to clot at room temperature for 15-20 min and then centrifuged for $20 \min (1,500 \times g)$. All samples were stored at $-80{ }^{\circ} \mathrm{C}$ until assayed. 


\subsection{Analytical method}

LSF serum concentrations were determined by a previously described chiral HPLC method (Wyska et al. 2006). Briefly, each tissue was homogenized in $0.1 \mathrm{M}$ phosphate buffered saline $(1: 4 \mathrm{w} / \mathrm{v})$. Serum $(0.2 \mathrm{ml})$ or tissue homogenates $(1 \mathrm{ml})$ were mixed with temazepam (internal standard). Then the samples were acidified with $40 \mu \mathrm{l} \mathrm{M}$ $\mathrm{HCl}$ and extracted with $5 \mathrm{ml}$ of dichloromethane. After centrifugation $(1,000 \times g, 15 \mathrm{~min})$, the organic layer was transferred to a new tube, then evaporated to dryness at $37{ }^{\circ} \mathrm{C}$ under a gentle stream of nitrogen. The residue was dissolved in $100 \mu \mathrm{l}$ of mobile phase, and $50 \mu \mathrm{l}$ of this solution was injected into the HPLC system. The HPLC system (Thermo Separation Products, San Jose, CA, USA) consisted of a P100 isocratic pump, a Rheodyne 7,125 injector (Rheodyne, Cotati, CA, USA) with a 50- $\mu$ l sample loop, an UV100 variable-wavelength UV/VIS detector, operating at $275 \mathrm{~nm}$, and an SP4400 (ChromJet) integrator. All analyses were performed at ambient temperature on a $250 \mathrm{~mm} \times 4.6 \mathrm{~mm}$ Chiralpak AD column (Daicel Corp., Japan) with $10 \mu \mathrm{m}$ particles, protected with a $20 \mathrm{~mm} \times 4.6 \mathrm{~mm}$ LC-Si guard-column (Supelco Inc., Bellefonte, PA, USA). The mobile phase consisting of hexane-2-propanol-diethylamine $(78: 22: 0.01 \mathrm{v} / \mathrm{v} / \mathrm{v})$ was pumped at a flow rate of $1 \mathrm{ml} / \mathrm{min}$. The method was linear from 0.05 to $60 \mu \mathrm{g} / \mathrm{ml}$. The intra-day and inter-day precisions were less than $10 \%$ and the recovery ranged from 72 to $95 \%$ depending on the type of tissue.

\subsection{Physiologically based pharmacokinetic model}

The PBPK model used to describe pharmacokinetics of LSF included separate compartments for each studied tissue as well as the arterial and venous plasma compartments
(Fig. 2). It was assumed that the compartments were well mixed and the drug concentration in venous plasma leaving a tissue was in equilibrium with that in the tissue. All nonsampled tissues were pooled together into a remainder compartment.

Changes of drug concentrations over time in individual compartments were described by the following mass-balance differential equations:

Brain (Br)

$\frac{V_{\mathrm{Br}} \times \mathrm{d} C_{\mathrm{Br}}}{\mathrm{d} t}=Q_{\mathrm{Br}} \times\left(C_{\mathrm{A}}-\frac{C_{\mathrm{Br}}}{P_{\mathrm{Br}}}\right)$

Muscle $(\mathrm{Mu})$

$\frac{V_{\mathrm{Mu}} \times \mathrm{d} C_{\mathrm{Mu}}}{\mathrm{d} t}=Q_{\mathrm{Mu}} \times\left(C_{\mathrm{A}}-\frac{C_{\mathrm{Mu}}}{P_{\mathrm{Mu}}}\right)$

Kidneys (Ki)

$\frac{V_{\mathrm{Ki}} \times \mathrm{d} C_{\mathrm{Ki}}}{\mathrm{d} t}=Q_{\mathrm{Ki}} \times\left(C_{\mathrm{A}}-\frac{C_{\mathrm{Ki}}}{P_{\mathrm{Ki}}}\right)-C L_{\mathrm{R}} \times C_{\mathrm{A}}$

Liver (Li)

$\begin{aligned} \frac{V_{\mathrm{Li}} \times \mathrm{d} C_{\mathrm{Li}}}{\mathrm{d} t}= & C_{\mathrm{A}} \times\left(Q_{\mathrm{Li}}-Q_{\mathrm{Gu}}\right)+Q_{\mathrm{Gu}} \times\left(\frac{C_{\mathrm{Gu}}}{P_{\mathrm{Gu}}}\right)-Q_{\mathrm{Li}} \\ & \times\left(\frac{C_{\mathrm{Li}}}{P_{\mathrm{Li}}}\right)-\frac{V_{\max }}{f_{\mathrm{uT}} \times C_{\mathrm{Li}}+K_{\mathrm{M}} \times P_{\mathrm{Li}}} \times f_{\mathrm{uT}} \times C_{\mathrm{Li}}\end{aligned}$

Gut $(\mathrm{Gu})$

$\frac{V_{\mathrm{Gu}} \times \mathrm{d} C_{\mathrm{Gu}}}{\mathrm{d} t}=Q_{\mathrm{Gu}} \times\left(C_{\mathrm{A}}-\frac{C_{\mathrm{Gu}}}{P_{\mathrm{Gu}}}\right)$

Lungs $(\mathrm{Lu})$

$\frac{V_{\mathrm{Lu}} \times \mathrm{d} C_{\mathrm{Lu}}}{\mathrm{d} t}=Q_{\mathrm{Lu}} \times\left(C_{\mathrm{V}}-\frac{C_{\mathrm{Lu}}}{P_{\mathrm{Lu}}}\right)$
Fig. 2 Physiologically based model for the pharmacokinetics of LSF in mice

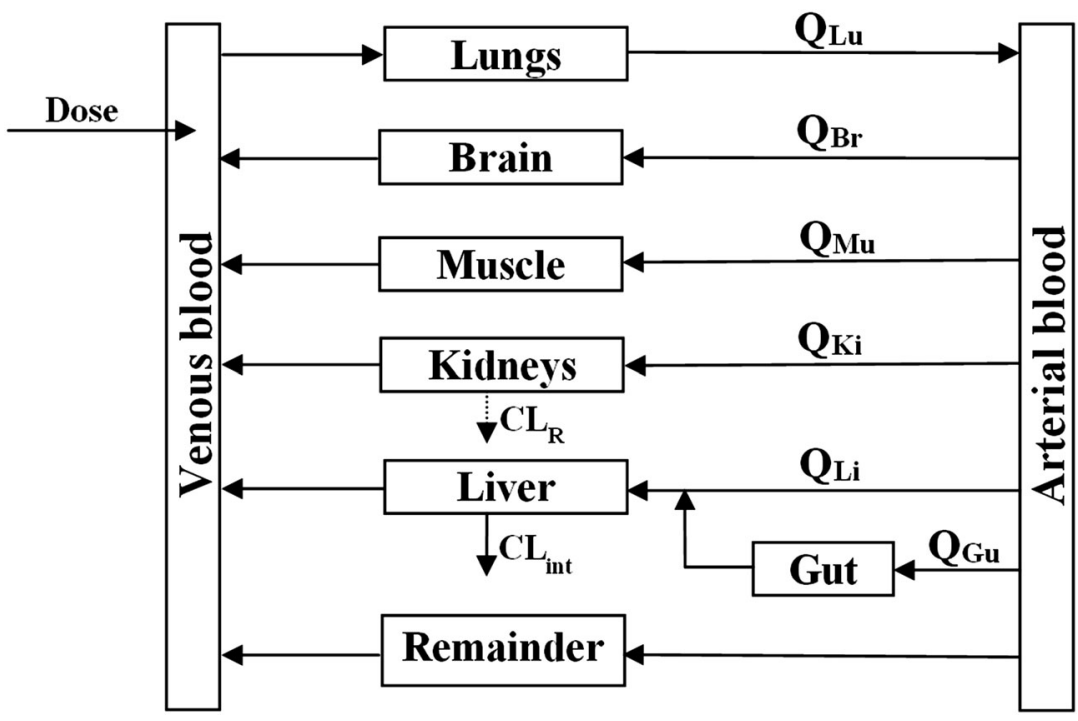


Remainder ( $\mathrm{Re})$

$\frac{V_{\mathrm{Re}} \times \mathrm{d} C_{\mathrm{Re}}}{\mathrm{d} t}=Q_{\mathrm{Re}} \times\left(C_{\mathrm{A}}-C_{\mathrm{Re}}\right)$

Arterial blood (A)

$\frac{V_{\mathrm{A}} \times \mathrm{d} C_{\mathrm{A}}}{\mathrm{d} t}=Q_{\mathrm{Lu}} \times\left(\frac{C_{\mathrm{Lu}}}{P_{\mathrm{Lu}}}-C_{\mathrm{A}}\right)$

Venous blood (V)

$$
\begin{aligned}
\frac{V_{\mathrm{V}} \times \mathrm{d} C_{\mathrm{V}}}{\mathrm{d} t}= & {\left[Q_{\mathrm{Br}} \times\left(\frac{C_{\mathrm{Br}}}{P_{\mathrm{Br}}}\right)+Q_{\mathrm{Mu}} \times\left(\frac{C_{\mathrm{Mu}}}{P_{\mathrm{Mu}}}\right)+Q_{\mathrm{Ki}} \times\left(\frac{C_{\mathrm{Ki}}}{P_{\mathrm{Ki}}}\right)\right.} \\
& \left.+Q_{\mathrm{Li}} \times\left(\frac{C_{\mathrm{Li}}}{P_{\mathrm{Li}}}\right)+Q_{\mathrm{Re}} \times C_{\mathrm{Re}}+\operatorname{In}(t)\right]-Q_{\mathrm{Lu}} \\
& \times C_{\mathrm{V}},
\end{aligned}
$$

where $V$ is tissue weight or volume, $Q$ is blood flow, $P$ represents the tissue-to-serum partition coefficient, $\mathrm{CL}_{\mathrm{R}}$ is the renal clearance, $V_{\max }$ represents the maximum rate of metabolism, $K_{\mathrm{M}}$ is the LSF concentration at which metabolism is occurring at $50 \%$ of the maximum rate, $\operatorname{In}(t)$ is the drug input rate, and $f_{\mathrm{uT}}$ is the fraction unbound in the liver. It was assumed that the compound was distributed homogenously throughout liver water and that the unbound concentrations in liver water and serum were identical. The fraction unbound in murine serum was assumed to be 0.76 (authors' own unpublished data obtained ex vivo using ultrafiltration). The model parameters, such as blood flows and tissue weights or volumes that were not estimated, were obtained from the literature. The tissue-to-serum partition coefficients were calculated using the area method proposed by Gallo et al. (1987) (Table 1). The areas under the serum and tissue

Table 1 Fixed parameters for the PBPK model of LSF in mice (Brown et al. 1997; Davies and Morris 1993)

\begin{tabular}{lccl}
\hline Tissue & $\begin{array}{l}\text { Blood flow } \\
(\mathrm{ml} / \mathrm{min})^{\mathrm{a}}\end{array}$ & $\begin{array}{l}\text { Weight } \\
\text { or volume } \\
(\mathrm{g} \text { or } \mathrm{ml})^{\mathrm{b}}\end{array}$ & $\begin{array}{l}\text { Tissue-to-serum } \\
\text { partition } \\
\text { coefficient }(P)\end{array}$ \\
\hline Brain & 0.47 & 0.50 & 0.345 \\
Muscle & 0.91 & 11.40 & 0.640 \\
Kidneys & 1.27 & 0.50 & 0.777 \\
Liver & 2.25 & 1.65 & 0.859 \\
Gut & 1.50 & 1.50 & 0.892 \\
Lungs & 13.98 & 0.22 & 0.758 \\
Remainder & 7.58 & 13.05 & - \\
Arterial blood & - & 0.24 & - \\
Venous blood & - & 0.94 & - \\
\hline
\end{tabular}

${ }^{a}$ Blood flow to remainder was calculated as the difference between the blood flow to lungs and the sum of blood flows to the other tissues

b Weight of remainder was calculated as the difference between total body weight $(30 \mathrm{~g})$ and the sum of the other tissue weights concentration-time curves (AUCs) were estimated by the linear trapezoidal rule with Phoenix WinNonlin v. 6.3 (Certara USA, Inc., St Louis, MO). The PBPK model (Fig. 2) was fitted simultaneously to 7 mean concentration versus time profiles following intravenous LSF administration to mice. The initial conditions for Eqs. 18 were set to zero. The maximum likelihood method in the ADAPT II software (D’Argenio and Schumitzky 1997) was used to estimate unknown model parameters. The model of variance was as follows:

$\operatorname{var}(C)=\left(\sigma_{1}+\sigma_{2} \times Y\right)^{2}$

where $Y$ is the model-predicted LSF concentration, and $\sigma_{1}$ and $\sigma_{2}$ are the variance model parameters. The goodnessof-fit was assessed using standard criteria (Gabrielsson and Weiner 1997).

Based on the developed PBPK model and human tissue weights or volumes and blood flows, LSF concentrationtime profiles were simulated in serum and tissues in human subjects following intravenous or oral administration. Model parameters used for these predictions are listed in Table 2. It was assumed that $\mathrm{P}$ values did not differ between species. Because in humans LSF is metabolized via more than one pathway, the intrinsic clearances of these pathways were summed up. The values of $V_{\max }$ and $K_{\mathrm{M}}$ obtained using human liver microsomes were taken from literature (Lee and Slattery 1997; Shin and Slattery 1998). In vivo whole liver intrinsic clearance $\left(\mathrm{CL}_{\mathrm{int}}\right)$ was calculated according to the following equation (Edwards et al. 2011):

$\mathrm{CL}_{\text {intinvivo }}=\sum \frac{V_{\max (\mathrm{i})}}{K_{\mathrm{M}(i)}} \times \frac{45 \mathrm{mg} \text { of microsomal protein }}{\mathrm{g} \text { of liver weight }} \times$ liver weight

where $V_{\max (i)}$ is maximum metabolic rate for enzyme $i$ and $K_{\mathrm{M}}$ is Michaelis-Menten constant for enzyme $i$.

Table 2 Parameters for the PBPK model of LSF used for simulations of pharmacokinetics and tissue distribution of this compound in a 70-kg human subject (Brown et al. 1997; Davies and Morris 1993)

\begin{tabular}{lcc}
\hline Tissue & Blood flow $(\mathrm{ml} / \mathrm{min})$ & Weight or volume $(\mathrm{g}$ or $\mathrm{ml})$ \\
\hline Brain & 700 & 1,400 \\
Muscle & 750 & 35,000 \\
Kidneys & 1,240 & 310 \\
Liver & 1,450 & 1,800 \\
Gut & 1,100 & 1,650 \\
Lungs & 5,600 & 1,000 \\
Remainder & 360 & 24,290 \\
Arterial blood & - & 1,000 \\
Venous blood & - & 3,550 \\
\hline
\end{tabular}


As LSF has a linear pharmacokinetics in humans (Bursten et al. 1998), for simulations a single parameter, $C L_{i n t}$ in vivo was used in Eq. 4 to describe the rate of LSF hepatic metabolism.

The in vivo hepatic plasma clearance $\left(\mathrm{CL}_{\mathrm{H}}\right)$ was subsequently calculated using the modified well-stirred model (Wilkinson and Shand 1975):

$\mathrm{CL}_{\mathrm{H}}=\frac{Q_{\mathrm{H}} \times f_{\mathrm{u}} \times \mathrm{CL}_{\mathrm{int}}}{Q_{\mathrm{H}}+f_{\mathrm{u}} \times C L_{\mathrm{int}} /\left(C_{\mathrm{B}} / C_{\mathrm{p}}\right)}$,

where $f_{\mathrm{u}}$ is the fraction unbound in plasma. For LSF the value of $f_{\mathrm{u}}$ in human plasma is 0.54 , whereas blood to plasma LSF concentration ratio $\left(C_{\mathrm{B}} / C \mathrm{p}\right)$ is 0.77 (Nicklasson et al. 2002).

For simulations of the time courses of LSF concentrations after oral administration to human subjects, the input function, $\operatorname{In}(t)$ was described by the following equation:

$\operatorname{In}(t)=F \times$ Dose $\times k_{\mathrm{a}} \times \mathrm{e}^{-k_{\mathrm{a}} \times t}$

where $k_{\mathrm{a}}$ represents a first-order absorption rate constant, $F$ is the fraction of the dose absorbed following oral administration, and $t$ is time. The values of $k_{\mathrm{a}}$ and $F$ used for simulations were obtained from a pharmacokinetic study in mice and equaled $0.024 \mathrm{~min}^{-1}$ and 0.16 , respectively (Wyska et al. 2007).

The simulated concentration versus time profile obtained in human serum after LSF administration at a dose of $3 \mathrm{mg} / \mathrm{kg}$ as a short-term intravenous infusion over $10 \mathrm{~min}$ was compared with that available in literature (Bursten et al. 1998). The data for comparison were extracted with Graph Digitizer software v. 2.0 (Brothersoft).

\section{Results and discussion}

PBPK models allow for the integration of physiological, biochemical, and anatomical data from different sources to estimate pharmacokinetic parameters and predict plasma and tissue concentration-time profiles. The most important advantages of developing PBPK models are the possibility to investigate drug concentrations in animal organs that could otherwise never be assessed in humans and the possibility to extrapolate the model to higher species by taking into account their organ volumes and blood flows, and adjusting for the differences in metabolism, plasma protein binding, and blood/plasma partition ratio between species. In addition, PBPK modeling is a useful tool to gain insights into the properties of a compound. The application of these models in drug development has been limited for many years mainly due to the mathematical complexity of this approach and the labor-intensive input data required for the model building process. Recent advances in the prediction of intestinal absorption, hepatic metabolism, and tissue distribution from in vitro data have resulted in more frequent use of these models (Jones et al. 2006; Parrott et al. 2005). Moreover, several PBPK simulation tools have become commercially available (e.g., GastroPlus, Cloe PK, or PK-Sim).

In the present study, this approach was used to evaluate plasma pharmacokinetics and tissue distribution of a drug candidate, LSF, in mice. The mean LSF concentrationtime profiles in serum and all sampled tissues following intravenous administration of this compound are presented in Fig. 3. LSF attained high concentrations in all tissues comparable to those observed in serum with the exception of brain, where concentrations measured were several times lower. These observations are confirmed by the tissue-to-serum partition coefficients $(P)$ calculated based on the areas under the concentration-time curves (AUCs) listed in Table 1. The value of this coefficient was the highest for the gut (0.892), followed by the liver tissue (0.859), whereas the $P$ value for the brain tissue was the lowest (0.345). In mice this compound was eliminated from the body very fast, and $60 \mathrm{~min}$ following dosing its concentrations dropped below $1 \mu \mathrm{g} / \mathrm{ml}$ in most studied tissues. All concentration versus time profiles were fitted simultaneously using the PBPK model shown in Fig. 2. The model-predicted profiles, shown in Fig. 3, demonstrate good agreement with the experimental data. The values of estimated model parameters are presented in Table 3. The relatively low $\mathrm{CV} \%$ values are also indicative of good model fitting. The intrinsic clearance calculated based on the estimated values of $V_{\max }$ are $K_{\mathrm{M}}$ was $5.427 \mathrm{ml} / \mathrm{min}$. Assuming that the blood to plasma ratio is constant across species, the hepatic plasma clearance calculated according to Eq. 12 is $1.22 \mathrm{ml} / \mathrm{min}$. This value is close to in vivo total clearance $(1.44 \mathrm{ml} / \mathrm{min})$ estimated based on the LSF serum concentration-time profile obtained in the present study using a one-compartment pharmacokinetic model in Phoenix WinNonlin v. 6.3. PBPK modeling indicated extremely low $\mathrm{CL}_{\mathrm{R}}$ of LSF in mice. Thus, the value of this parameter was fixed to zero in the final model. This observation was confirmed by the results of the experiment performed in our laboratory in order to assess a percent of LSF excreted unchanged with urine. For this purpose, three mice were given an intravenous dose of $50 \mathrm{mg} / \mathrm{kg} \mathrm{LSF}$ and they were placed in metabolic cages. All excreted urine was collected after 2 and $4 \mathrm{~h}$ following LSF administration. The volumes of urine samples were recorded and drug concentrations in each sample were measured using the chiral HPLC method described in the Sect. 2 after validation for murine urine. The calculated mean percentage of LSF dose excreted unchanged with urine within $4 \mathrm{~h}$ was as low as $0.71 \pm 0.13 \%$ (unpublished data).

The PBPK model and the final estimated parameters (Table 3) were used to simulate the time course of LSF 

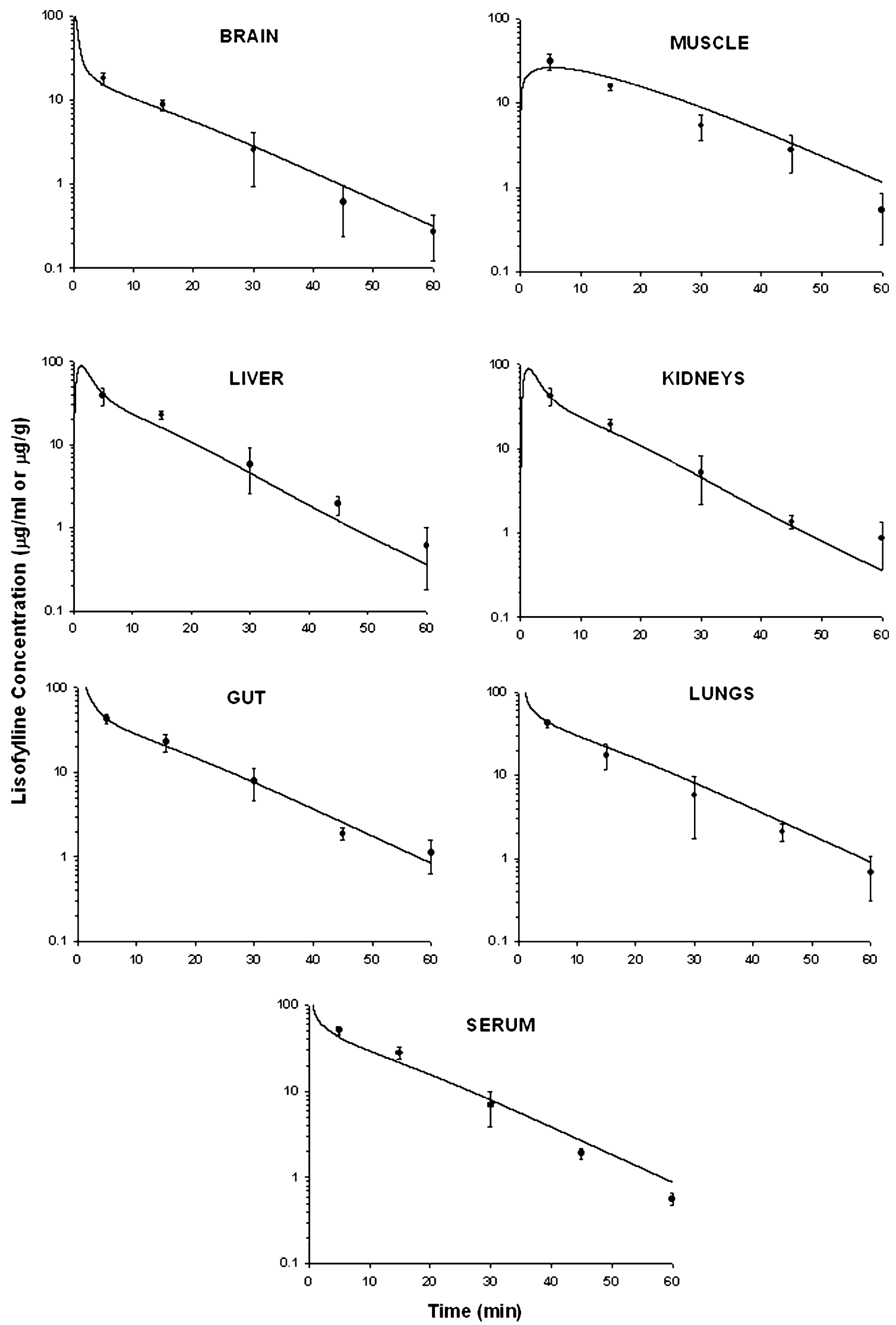

Fig. 3 Time course of observed (symbols) and PBPK model predicted (lines) LSF concentrations in serum and tissues 
Table 3 Final PBPK model parameters of LSF

\begin{tabular}{llc}
\hline Parameter & Estimate & $\mathrm{CV}(\%)$ \\
\hline $\mathrm{CL}_{\mathrm{R}}(\mathrm{ml} / \mathrm{min})$ & 0 (fixed) & - \\
$V_{\max }(\mu \mathrm{g} / \mathrm{min})$ & 9.644 & 30.34 \\
$K_{\mathrm{M}}(\mu \mathrm{g} / \mathrm{ml})$ & 1.777 & 89.52 \\
$\sigma_{1}$ & 0.311 & 15.50 \\
$\sigma_{2}$ & 0.250 & 10.86 \\
\hline
\end{tabular}

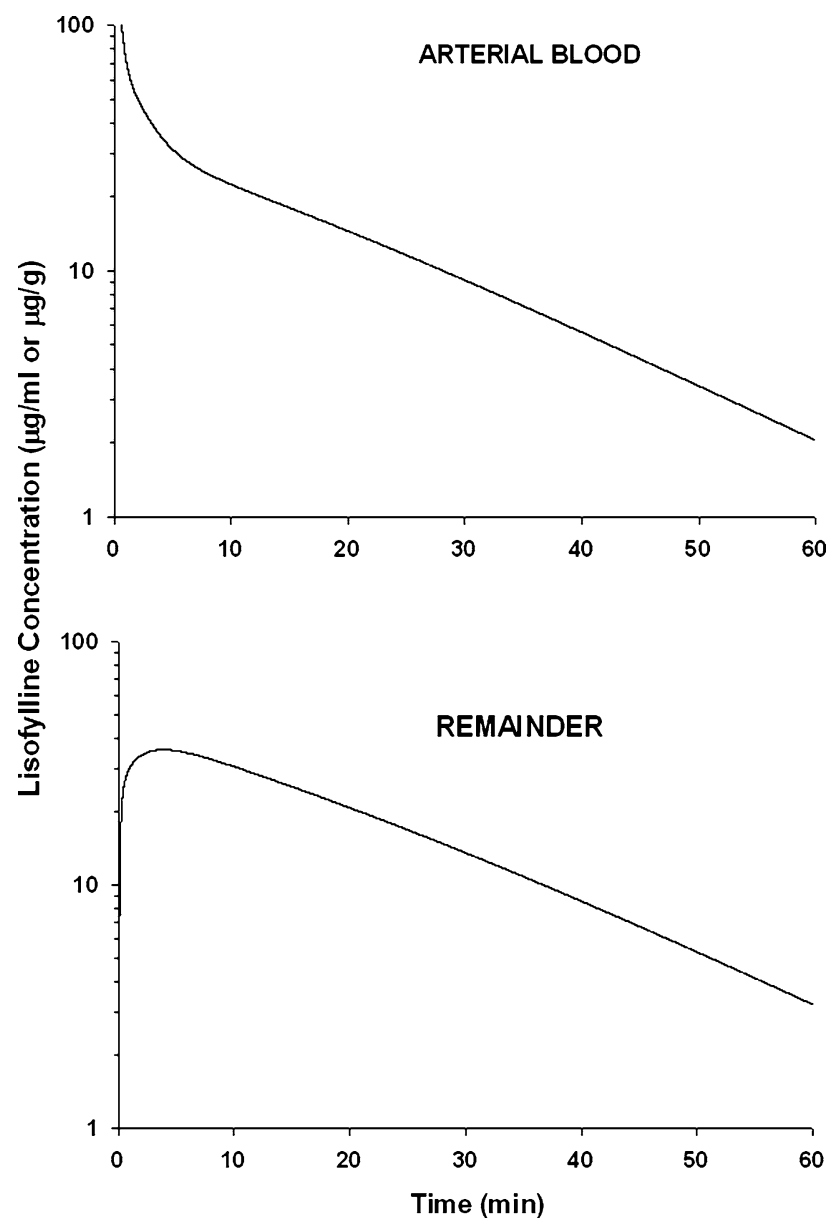

Fig. 4 Simulated LSF concentrations in the arterial (upper panel) and remainder (lower panel) compartments in mice using the PBPK model and estimated parameters

concentrations in the arterial and remainder compartments (Fig. 4). The simulated profile in the arterial compartment indicates that LSF concentrations are similar in both arterial and venous plasma; thus, rapid equilibrium between both compartments occurred. LSF concentrations observed in the remainder compartment increase more slowly to relatively high peak values and decrease in parallel with the terminal phase of LSF elimination in the other studied tissues. This observation may have a clinical significance, for example, in autoimmune disorders such as rheumatoid
Fig. 5 PBPK-model simulated LSF concentration versus time profiles in human serum and tissues following a 10 min intravenous infusion (solid line) and oral administration (dashed line) of an LSF dose of 3 and $6 \mathrm{mg} / \mathrm{kg}$, respectively. Symbols represent LSF concentrations measured in plasma of human subjects receiving this compound intravenously at a dose of $3 \mathrm{mg} / \mathrm{kg}$ (Bursten et al. 1998) and dotted lines represent the pharmacokinetic profiles following oral administration of a dose of $6 \mathrm{mg} / \mathrm{kg}$ predicted based on the human oral absorption data (for more explanation see the text)

arthritis, where drugs must reach their target sites in concentrations sufficient to exert their pharmacologic effects.

Figure 5 shows the LSF concentration-time profiles in human serum and tissues after a 10 min intravenous infusion and oral administration of a dose of 3 and $6 \mathrm{mg} / \mathrm{kg}$, respectively, simulated based on the PBPK model. The blood flows and organ weights or volumes used for simulations are presented in Table 2, whereas the in vivo intrinsic clearance was determined from data obtained using human liver microsomes. It has been shown that LSF is metabolized in human liver microsomes by the cytochrome P450 to two principal metabolites, lisofylline 4,5-diol and pentoxifylline. Lisofylline diol formation is biphasic, with $K_{\mathrm{M}}$ values of 0.0230 and $4.23 \mathrm{mM}$ and the respective $V_{\max }$ values of 0.0565 and $0.429 \mathrm{nmol} / \mathrm{min} / \mathrm{mg}$ of protein (Shin and Slattery 1998). The low and high $K_{\mathrm{M}}$ enzymes are CYP3A4 and CYP2A6. Similarly, a biphasic model best described the data for the formation of pentoxifylline from LSF. $K_{\mathrm{M}}$ values were 0.282 and $158 \mu \mathrm{M}$, and the respective $V_{\max }$ values equaled to 0.003 and $0.928 \mathrm{nmol} / \mathrm{min} / \mathrm{mg}$. The low $K_{\mathrm{M}}$ enzyme was not a cytochrome P450, whereas the high-affinity enzyme was CYP1A2 (Lee and Slattery 1997). The in vivo whole liver intrinsic clearance of LSF calculated based on these data and Eq. 11 was $1,545.24 \mathrm{ml} /$ min. As presented in Fig. 5, the predicted by the PBPK model LSF concentration versus time profile in serum following intravenous administration was very close to the concentrations observed in human subjects receiving the same dose of LSF by the same route of administration. The plasma hepatic clearance calculated based on the in vivo intrinsic clearance (Eq. 12) was $477.54 \mathrm{ml} / \mathrm{min}$. This value was considerably lower than the total clearance calculated based on the data digitalized from the paper describing the human study on LSF pharmacokinetics $(1,282.88 \mathrm{ml} / \mathrm{min})$ (Bursten et al. 1998). Therefore, it can be assumed that other pathways of LSF elimination than hepatic metabolism exist in humans. An attempt was also made to calculate the hepatic plasma clearance of LSF in humans based on the hepatic clearance determined in mice and blood flows according to the equation: human clearance $=$ animal clearance $\times$ (human liver blood flow/animal liver blood flow) (Ward and Smith 2004). The value of human clearance obtained using this method 

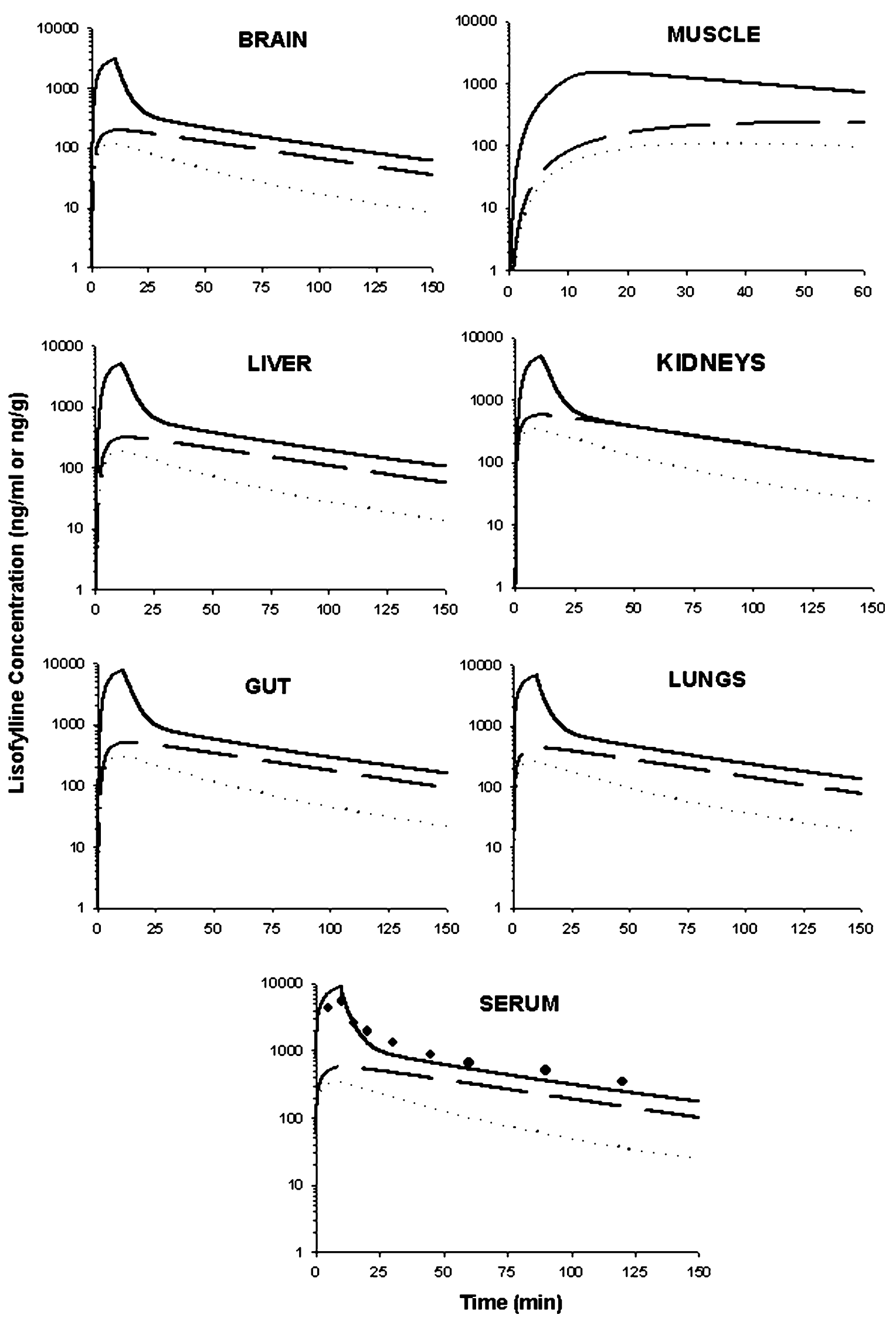
(766.89 $\mathrm{ml} / \mathrm{min}$ ) was higher than that derived from in vitro data, but still significantly lower than the total clearance of LSF in humans.

The simulated profile obtained following oral dosing was slightly different from the observed values. Following an oral administration of a dose of $6 \mathrm{mg} / \mathrm{kg} \mathrm{LSF}$ to human subjects the maximum concentration $\left(C_{\max }\right)$ was $226 \pm 99.10 \mathrm{ng} / \mathrm{ml}$ and time to $C_{\max }$ was $0.53 \pm 0.26 \mathrm{~h}$ (Bursten et al. 1998). The values of these parameters obtained from the simulated concentration versus time curve following the same oral dose of LSF (Fig. 5) were $572.12 \mathrm{ng} / \mathrm{ml}$ and $10.6 \mathrm{~min}$, respectively. Despite an overestimation of $C_{\max }$ after oral administration, the model describes the terminal slope satisfactorily. The discrepancy between the pharmacokinetic parameters estimated from observed and predicted data may be explained by the fact that $k_{\mathrm{a}}$ and $F$ values used for simulations were estimated based on the data obtained from mice (Wyska et al. 2007). In humans the bioavailability of LSF was calculated to be $5.9 \%$ (Bursten et al. 1998), whereas in mice this parameter was $16 \%$. The dashed and dotted lines in Fig. 5 represent simulations based on the values of $\mathrm{k}_{\mathrm{a}}$ and $\mathrm{F}$ obtained from murine and human pharmacokinetic data, respectively. In both cases, LSF concentrations in serum and tissues studied were considerably lower in comparison to the profiles obtained following intravenous administration of the 2-times lower dose, namely $3 \mathrm{mg} / \mathrm{kg}$ and may be insufficient to exert any pharmacological effect.

From Fig. 5 it seems that the mouse is a good model to study LSF pharmacokinetics following intravenous administration. It is not surprising as CYP3A plays an important role in LSF metabolism. In a comparison of several species, the mouse was identified as the most similar to humans with respect to catalytic activities of this isozyme (Bogaards et al. 2000). However, in the case of oral dosing the prediction was not perfect when incorporating pharmacokinetic parameters obtained from mice into the model. This may indicate different mechanisms involved in LSF absorption from the gastrointestinal tract in both species.

\section{Conclusions}

In conclusion, pharmacokinetics of LSF following intravenous administration in mice have been presented and assessed quantitatively using a PBPK model. The model captured the experimental data very well. The predicted LSF concentrations in human serum following intravenous administration were very close to the observed concentrations indicating that the mouse is a good model to study pharmacokinetics of this compound. The developed PBPK model may be useful in the design and analysis of future preclinical and clinical studies of LSF.
Acknowledgments We thank dr hab. Elzbieta Pękala for providing lisofylline. This work was supported by Statutory Funds of the Jagiellonian University Medical College, Cracow, Poland (K/ZDS/ 004706).

Open Access This article is distributed under the terms of the Creative Commons Attribution Noncommercial License which permits any noncommercial use, distribution, and reproduction in any medium, provided the original author(s) and the source are credited.

\section{References}

Abraham E, Bursten S, Shenkar R, Allbee J, Tuder R, Woodson P, Guidot DM, Rice G, Singer JW, Repine JE (1995) Phosphatidic acid signaling mediates lung cytokine expression and lung inflammatory injury after hemorrhage in mice. J Exp Med 181:569-575

ARDS Clinical Trials Network, National Heart, Lung, and Blood Institute, National Institutes of Health (2002) Randomized, placebo-controlled trial of lisofylline for early treatment of acute lung injury and acute respiratory distress syndrome. Crit Care Med 30:1-6

Bleich D, Chen S, Bursten SL, Nadler JL (1996) Lisofylline, an inhibitor of unsaturated phosphatidic acid generation, ameliorates interleukin-1 beta-induced dysfunction in cultured rat islets. Endocrinology 137:4871-4877

Bogaards JJ, Bertrand M, Jackson F, Oudshoorn MJ, Weaver RJ, van Bladeren PJ, Walther B (2000) Determining the best animal model for human cytochrome P450 activities: a comparison of mouse, rat, rabbit, dog, micropig, monkey and man. Xenobiotica 30:1131-1152

Bright JJ, Du C, Coon M, Sriram S, Klaus SJ (1998) Prevention of experimental allergic encephalomyelitis via inhibition of IL-12 signaling and IL-12-mediated Th1 differentiation: an effect of the novel anti-inflammatory drug lisofylline. J Immunol 161:7015-7022

Brown RP, Delp MD, Lindstedt SL, Rhomberg LR, Beliles RP (1997) Physiological parameter values for physiologically based pharmacokinetic models. Toxicol Ind Health 13:407-484

Bursten SL, Federighi D, Wald J, Meengs B, Spickler W, Nudelman E (1998) Lisofylline causes rapid and prolonged suppression of serum levels of free fatty acids. J Pharmacol Exp Ther 284:337-345

Clarke E, Rice GC, Weeks RS, Jenkins N, Nelson R, Bianco JA, Singer JW (1996) Lisofylline inhibits transforming growth factor beta release and enhances trilineage hematopoietic recovery after 5-fluorouracil treatment in mice. Cancer Res 56:105-112

D’Argenio DZ, Schumitzky A (1997) ADAPT II user's guide: pharmacokinetic/pharmacodynamic systems analysis software. Biomedical Simulations Resource, Los Angeles

Davies B, Morris T (1993) Physiological parameters in laboratory animals and humans. Pharm Res 10:1093-1095

Edwards LD, Fox AW, Stonier PD (2011) Principles and practice of pharmaceutical medicine, 3rd edn. Wiley-Blackwell, Oxford

Gabrielsson J, Weiner D (1997) Pharmacokinetic and pharmacodynamic data analysis: concepts and applications, 2nd edn. Swedish Pharmaceutical Press, Stockholm

Gallo JM, Lam FC, Perrier DG (1987) Area method for the estimation of partition coefficients for physiological pharmacokinetic models. J Pharmacokinet Biopharm 15:271-280

Hasegawa N, Oka Y, Nakayama M, Berry GJ, Bursten S, Rice G, Raffin TA (1997) The effects of post-treatment with lisofylline, a phosphatidic acid generation inhibitor, on sepsis-induced acute lung injury in pigs. Am J Respir Crit Care Med 155:928-936 
Hybertson BM, Bursten SL, Leff JA, Lee YM, Jepson EK, Dewitt CR, Zagorski J, Cho HG, Repine JE (1997) Lisofylline prevents leak, but not neutrophil accumulation, in lungs of rats given IL-1 intratracheally. J Appl Physiol 82:226-232

Jones HM, Parrott N, Jorga K, Lavé T (2006) A novel strategy for physiologically based predictions of human pharmacokinetics. Clin Pharmacokinet 45:511-542

Lee SH, Slattery JT (1997) Cytochrome P450 isozymes involved in lisofylline metabolism to pentoxifylline in human liver microsomes. Drug Metab Dispos 25:1354-1358

Liang Y, Pan H-F, Ye D-Q (2014) Therapeutic potential of STAT4 in autoimmunity. Expert Opin Ther Targets 18:945-960

List AF, Maziarz R, Stiff P, Jansen J, Liesveld J, Andrews F, Schuster M, Wolff S, Litzow M, Karanes C, Dahlberg S, Kirkhart B, Bianco JA, Singer JW (2000) A randomized placebo-controlled trial of lisofylline in HLA-identical, sibling-donor, allogeneic bone marrow transplant recipients. The lisofylline marrow transplant study group. Bone Marrow Transplant 25:283-291

Margolin K, Atkins M, Sparano J, Sosman J, Weiss G, Lotze M, Doroshow J, Mier J, O’Boyle K, Fisher R, Campbell E, Rubin J, Federighi D, Bursten S (1997) Prospective, randomized trial of lisofylline for the prevention of toxicities of high-dose interleukin-2 therapy in advanced renal cancer and malignant melanoma. Clin Cancer Res 3:565-572

National Institutes of Health (2009) A safety, tolerability and bioavailability study of lisofylline after continuous subcutaneous $(12 \mathrm{mg} / \mathrm{kg})$ and intravenous $(12 \mathrm{mg} / \mathrm{kg})$ administration in healthy subjects and in subjects with type 1 diabetes mellitus. In: ClinicalTrials.gov [Internet]. Bethesda (MD): National Library of Medicine (US). http://clinicaltrials.gov/show/ NCT00896077, NLM Identifier: NCT00896077. Accessed 14th Sept 2014

Nicklasson M, Björkman S, Roth B, Jönsson M, Höglund P (2002) Stereoselective metabolism of pentoxifylline in vitro and in vivo in humans. Chirality 14:643-652

Parrott N, Jones H, Paquereau N, Lave T (2005) Application of full physiological models for pharmaceutical drug candidate selection and extrapolation of pharmacokinetics to man. Basic Clin Pharmacol Toxicol 96:193-199

Rice GC, Brown PA, Nelson RJ, Bianco JA, Singer JW, Bursten S (1994a) Protection from endotoxic shock in mice by pharmacologic inhibition of phosphatidic acid. Proc Natl Acad Sci USA 91:3857-3861

Rice GC, Rosen J, Weeks R, Michnick J, Bursten S, Bianco JA, Singer JW (1994b) CT-1501R selectively inhibits induced inflammatory monokines in human whole blood ex vivo. Shock $1: 254-266$
Shin HS, Slattery JT (1998) CYP3A4-mediated oxidation of lisofylline to lisofylline 4,5-diol in human liver microsomes. J Pharm Sci 87:390-393

Striffler JS, Nadler JL (2004) Lisofylline, A novel anti-inflammatory agent, enhances glucose-stimulated insulin secretion in vivo and in vitro: studies in prediabetic and normal rats. Metabolism 53:290-296

van Furth AM, Verhard-Seijmonsbergen EM, van Furth R, Langermans JAM (1997) Effect of lisofylline and pentoxifylline on the bacterial-stimulated production of TNF- $\alpha$ IL- $1 \beta$ and IL-10 by human leucocytes. Immunology 91:193-196

Vries P, Singer JW (2000) Lisofylline suppresses ex vivo release by murine spleen cells of hematopoietic inhibitors induced by cancer chemotherapeutic agents. Exp Hematol 28:916-923

Ward KW, Smith BR (2004) A comprehensive quantitative and qualitative evaluation of extrapolation of intravenous pharmacokinetic parameters from rat, dog, and monkey to humans. I. Clearance. Drug Metab Disp 32:603-611

Wilkinson GR, Shand DG (1975) A physiological approach to hepatic drug clearance. Clin Pharmacol Ther 18:377-390

Wyska E (2009) Pretreatment with $\mathrm{R}(+)$-verapamil significantly reduces mortality and cytokine expression in murine model of septic shock. Int Immunopharmacol 9:478-490

Wyska E (2010a) Pharmacokinetic-pharmacodynamic modelling of methylxanthine derivatives in mice challenged with high-dose lipopolysaccharide. Pharmacology 85:264-271

Wyska E (2010b) Pharmacokinetic interaction between verapamil and methylxanthine derivatives in mice. Drug Metab Lett 4:15-24

Wyska E, Pękala E, Szymura-Oleksiak J (2006) Interconversion and tissue distribution of pentoxifylline and lisofylline in mice. Chirality 18:644-651

Wyska E, Szymura-Oleksiak J, Pękala E, Obruśnik A (2007) Pharmacokinetic modelling of pentoxifylline and lisofylline after oral and intravenous administration in mice. J Pharm Pharmacol 59:495-501

Yang ZD, Chen M, Wu R, McDuffie M, Nadler JL (2002) The antiinflammatory compound lisofylline prevents type I diabetes in non-obese diabetic mice. Diabetologia 45:1307-1314

Yang Z, Chen M, Fialkow LB, Ellett JD, Wu R, Nadler JL (2003) Inhibition of STAT4 activation by lisofylline is associated with the protection of autoimmune diabetes. Ann NY Acad Sci 1005:409-411

Yang Z, Chen M, Nadler JL (2005) Lisofylline: a potential lead for the treatment of diabetes. Biochem Pharmacol 69:1-5 